\title{
Cytotoxic Activity and DNA-Binding Properties of Isoeuxanthone Derivatives
}

\author{
Hui Fang Wang, ${ }^{* a, b}$ Hong Yan, ${ }^{a}$ Xianghua Gao, ${ }^{a}$ Baolong Niu, ${ }^{a}$ Ruijie Guo, ${ }^{a}$ Liqiao Wei, ${ }^{a}$ \\ Bingshe $\mathrm{Xu},{ }^{a, b}$ and Ning Tang $^{c}$ \\ ${ }^{a}$ Key Laboratory of Interface Science and Engineering in Advanced Materials, Ministry of Education, Taiyuan \\ University of Technology: ${ }^{b}$ Research Center of Advanced Materials Science and Technology, Taiyuan University of \\ Technology; Taiyuan 030024, P.R. China: and ${ }^{c}$ College of Chemistry and Chemical Engineering, Lanzhou University; \\ Lanzhou 730000, P. R. China.
}

Received October 8, 2013; accepted December 6, 2013

In this study, the interactions of different groups substituted isoeuxanthone derivatives with calf thymus DNA (ct DNA) were investigated by spectrophotometric methods and viscosity measurements. Results indicated that the xanthone derivatives could intercalate into the DNA base pairs by the plane of xanthone ring and the various substituents may influence the binding affinity with DNA according to the calculated quenching constant values. Furthermore, two tumor cell lines including the human cervical cancer cell line (HeLa) and human hepatocellular liver carcinoma cell line (HepG2) were used to evaluate the cytotoxic activities of xanthone derivatives by acid phosphatase assay. Analyses showed that the oxiranylmethoxy substituted xanthone exhibited more effective cytotoxic activity against the cancer cells than the other substituted xanthones. The effects on the inhibition of tumor cells in vitro agreed with the studies of DNA-binding.

Key words isoeuxanthone derivative; DNA-binding; intercalative mode; cytotoxic activity

Xanthones (or xanthen-9-ones) constitute a class of $O$ heterocycles with a dibenzo- $\gamma$-pyrone scaffold were commonly found as secondary metabolites in higher plants, fungi and lichens. ${ }^{1,2)}$ The xanthone classes bearing different types of substituents that were able to interact with several biological targets and exhibited various pharmacological properties such as antioxidant, ${ }^{3,4)}$ antimalarial $^{5)}$ and antiinflammatory activities, ${ }^{6)}$ inhibition of a variety of tumor cell lines' growth ${ }^{7-9)}$ and modulation of protein kinase C (PKC) isoforms. ${ }^{10)}$ The antitumor activity is one of the important biological activities in recent studies and it is related to their mode of interaction with DNA, where groove binding and intercalation are known to be important. The important features for intercalation have been suggested to be a fused tricyclic aromatic backbone and the presence of substituent side chains. ${ }^{11,12)}$ However, there are only a few systematic studies on the relationship of the structure and the DNA-binding ability. ${ }^{13)}$ So many researchers made major efforts aimed at clarifying the structure-activity correlation that could be used to guide the discovery of potent antitumor drugs for medical use.

We previously reported that the piperidinyl isoeuxanthone derivative and its metal complexes intercalated DNA with strong affinity and showed significant anticancer activity against human cancer cell lines. ${ }^{14,15)}$ The findings suggested that isoeuxanthone modulated with piperidinyl group exhibited more strong DNA-binding affinity and antitumor activity than isoeuxanthone itself. In our continued effort to develop anti-cancer drug candidates, a series of isoeuxanthone derivatives (Fig. 1) were synthesized with the expectation of increasing their binding ability toward DNA with the aim of elucidating binding preferences and cytotoxic potential in an attempt to identify lead compound for ongoing drug development. In this context, we hereby described the syntheses of four isoeuxanthone derivatives and investigated the interaction of them with calf thymus DNA (ct DNA) using absorption

The authors declare no conflict of interest. spectroscopy, fluorescence spectroscopy, ethidium bromide (EB) displacement experiments and viscosity measurements. In addition, the cytotoxic effects of the xanthones against the human cervical cancer cell line (HeLa) and human hepatocellular liver carcinoma cell line (HepG2) were evaluated by acid phosphatase assay. Analyses showed that the oxiranylmethoxy substituted xanthone exhibited more effective cytotoxic activity against the cancer cells than the other substituted xanthones.

\section{Experimental}

Materials Isoeuxanthone (1,6-dihydroxyxanthone) and its derivatives were prepared according to the literature ${ }^{16,17)}$ with some improvement. The other chemicals were reagent grade and used without further purification. ct DNA and EB were obtained from Sigma Chemical Co.

Instruments Mass spectra (MS) were performed on a VG ZAB-HS instrument and ${ }^{1} \mathrm{H}-\mathrm{NMR}$ spectra were recorded using a Varian Mercury Plus 400 spectrometer. The UV-Vis absorption spectra were recorded using a Varian Cary 100 spectrophotometer and the fluorescence emission spectra were recorded using a Hitachi F-4500 spectrofluorophotometer, respectively.

All the measurements involving the interactions of the isoeuxanthone derivatives with ct DNA were carried out in doubly distilled water buffer containing $5 \mathrm{~mm}$ Tris and $50 \mathrm{~mm}$ $\mathrm{NaCl}$, and adjusted to $\mathrm{pH} 7.1$ with hydrochloric acid. UV-Vis spectrometer was employed to check a solution of ct DNA purity $\left(A_{260}: A_{280}>1.80\right)$ and the concentration $\left(\varepsilon=6600 \mathrm{M}^{-1} \mathrm{~cm}^{-1}\right.$ at $260 \mathrm{~nm})$ in the buffer. ${ }^{18,19)}$ The xanthone compounds were first dissolved in a minimum amount of ethanol $(0.05 \%$ of the final volume), and then diluted with Tris- $\mathrm{HCl}$ buffer at concentration $5 \mu \mathrm{M}$.

Absorption and fluorescence titration experiments were performed at a constant concentration of the compounds $(10 \mu \mathrm{M})$ while varying DNA concentration. The competitive binding experiments were carried out by maintaining the EB and ct 
DNA concentration at $3 \mu \mathrm{M}$ and $30 \mu \mathrm{M}$, respectively, while increasing the concentrations of the compounds.

Viscosity experiments were carried out on an Ubbelodhe viscometer, immersed in a thermostated water-bath maintained at $25.0^{\circ} \mathrm{C}$. Titrations were performed for the compounds $(1-6 \mu \mathrm{M})$, and each compound was added into DNA solution $(50 \mu \mathrm{M})$ present in the viscometer. Flow time was measured with a digital stopwatch and each sample was measured three times and an average flow time was calculated. Data were presented as $\left(\eta / \eta_{0}\right)^{1 / 3}$ versus the ratio of the concentration of the compound to DNA, where $\eta$ is the viscosity of DNA in the presence of compound, and $\eta_{0}$ is the viscosity of DNA alone. Viscosity values were calculated from the observed flow time $(t)$ of DNA-containing solution corrected from the flow time of buffer alone $\left(t_{0}\right), \eta=t-t_{0} \cdot{ }^{20,21)}$

Preparation of Xanthone Derivatives 1-4 ${ }^{16,17)}$ The synthetic route of isoeuxanthone and its alkoxy derivatives 1-4 is shown in Fig. 1. Alkylation of isoeuxanthone with alkyl halides in acetone or $N, N$-dimethylformamide (DMF) afforded 1-4 in moderate to good yields (50-80\%). All the crude products were purified by chromatography on silicagel column and recrystallized to afford $\mathbf{1 - 4}$ as yellow solids.

1-Hydroxy-6-ethoxyxanthone (1): Yield 78.12\%, MS: 256.0 [M], ${ }^{1} \mathrm{H}-\mathrm{NMR}\left(400 \mathrm{MHz}, \mathrm{CDCl}_{3}\right) \delta: 12.82(\mathrm{~s}, 1 \mathrm{H}), 8.20-8.16$ (d, 1H), 7.60-7.52 (t, 1H), 6.98-6.77 (m, 4H), 4.23-4.13 (dd, $2 \mathrm{H}), 1.54-1.27(\mathrm{t}, 3 \mathrm{H}) \mathrm{ppm}$.

1-Hydroxy-6-butoxyxanthone (2): Yield $72.36 \%$, MS: 283.8 $[\mathrm{M}],{ }^{1} \mathrm{H}-\mathrm{NMR}\left(400 \mathrm{MHz}, \mathrm{CDCl}_{3}\right) \delta: 12.79(\mathrm{~s}, 1 \mathrm{H}), 8.16-8.12$

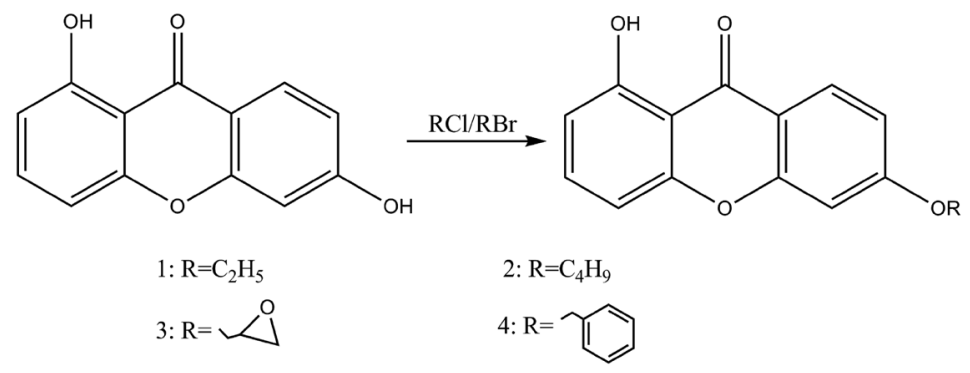

Fig. 1. Synthetic Route for Isoeuxanthone Derivatives 1-4
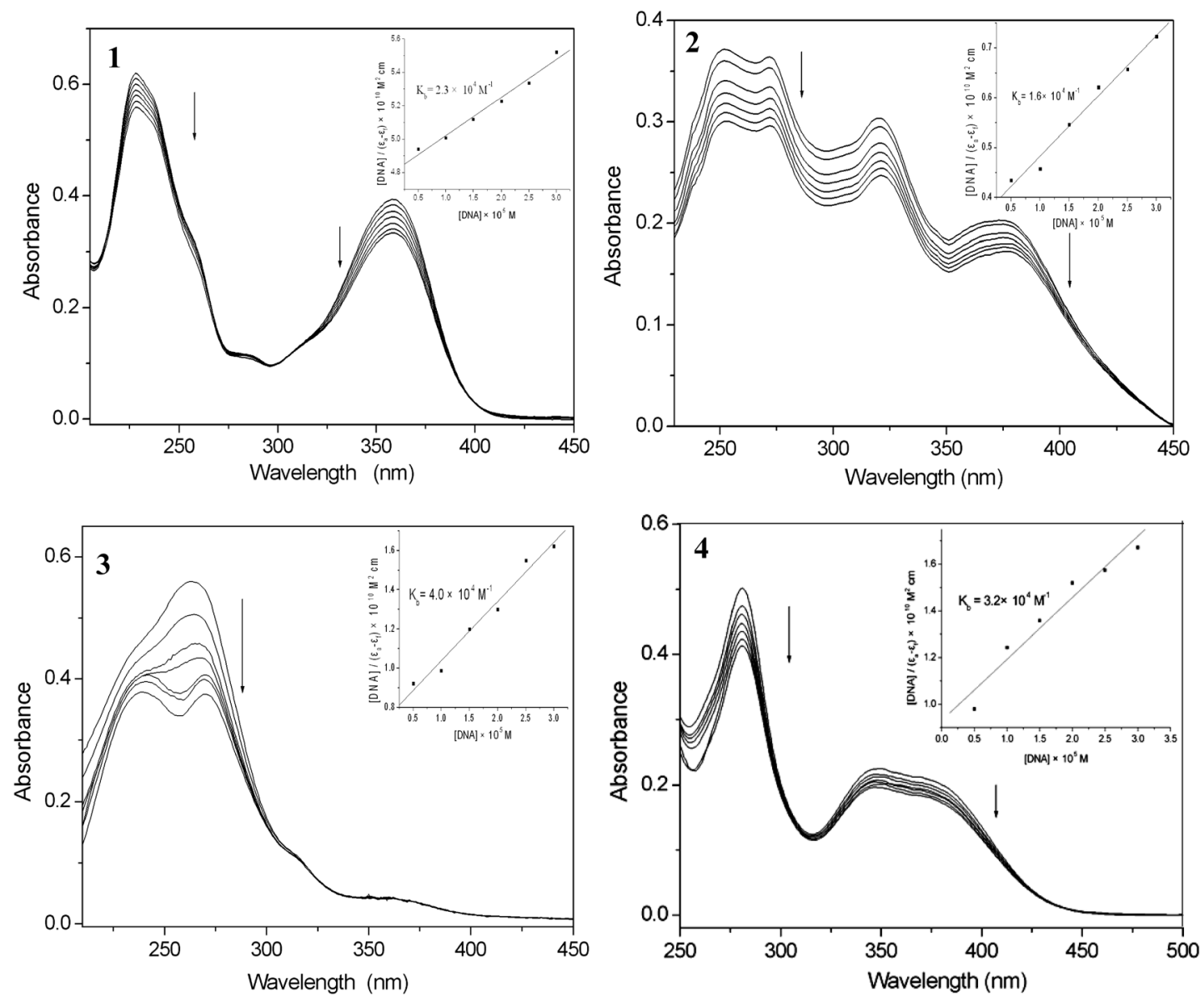

Fig. 2. UV-Vis Absorption Spectra of $\mathbf{1}-\mathbf{4}(10 \mu \mathrm{M})$ in the Presence of Increasing Amounts of ct DNA; [DNA] $=0,10,20,30,40,50,60 \mu \mathrm{M}$

The arrow indicates the absorbance changes upon increasing DNA concentration. The inset is plot of [DNA] $\left(\varepsilon_{\mathrm{b}}-\varepsilon_{\mathrm{f}}\right) v s$. [DNA] for the titration of DNA to the compounds. 
(d, 1H), 7.56-7.48 (t, 1H), 6.95-6.74 (m, 4H), 4.10-4.04 (t, 2H), 1.89-1.75 (m, $2 \mathrm{H}), 1.61-1.46(\mathrm{~m}, 2 \mathrm{H}), 1.03-0.95(\mathrm{t}, 3 \mathrm{H})$ ppm.

1-Hydroxy-6-benzyloxyxanthone (3): Yield 57.13\%, MS: $318.0[\mathrm{M}],{ }^{1} \mathrm{H}-\mathrm{NMR}\left(400 \mathrm{MHz}, \mathrm{CDCl}_{3}\right) \delta: 12.76$ (s, 1H), 8.20-8.17 (d, 1H), 7.57-7.52 (t, 1H), 7.47-7.38 (m, 5H), 7.04-7.01 (dd, 1H), 6.94-6.88 (m, 2H), 6.80-6.77 (d, 1H), 5.15 (s, 2H) ppm.

1-Hydroxy-6-(2-oxiranylmethoxy)xanthone (4): Yield 54.20\%, MS: 283.9 [M], ${ }^{1} \mathrm{H}-\mathrm{NMR}\left(400 \mathrm{MHz}, \mathrm{DMSO}-d_{6}\right) \delta$ : 12.80 (s, $1 \mathrm{H}), 8.13-8.10(\mathrm{~m}, 2 \mathrm{H}), 7.90-7.75(\mathrm{~m}, 2 \mathrm{H}), 7.36-7.34$ (d, 1H), 5.19-5.16 (t, 1H), 4.54-4.50 (m, 1H), 4.40-4.35 (m, $1 \mathrm{H}), 4.27-4.22(\mathrm{~m}, 1 \mathrm{H}), 3.80-3.67(\mathrm{~m}, 2 \mathrm{H}) \mathrm{ppm}$.

Acid Phosphatase Assay The cytotoxic activities were evaluated by acid phosphatase assay. The reagent, $p$ nitrophenyl phosphate ( $p$-NPP), was obtained from Amresco. The compounds 1-4 were dissolved in dimethyl sulphoxide (DMSO) and diluted in culture medium. The final concentration of DMSO in cultures was always not exceeding $0.5 \%$ (v/v), which did not cause toxicity. The HeLa and HepG2 cells obtained from ATCC were maintained in Dulbecco's modified Eagle's medium (DMEM) with 10\% fetal bovine serum (FBS), $100 \mathrm{U} / \mathrm{mL}$ penicillin and $100 \mathrm{mg} / \mathrm{mL}$ streptomycin. Cells were cultured at $37^{\circ} \mathrm{C}$ in a humidified atmosphere of $5 \% \mathrm{CO}_{2}$ in air.

Two different cell lines, HeLa and HepG2 were plated in 96-well plates. The adherent cells, HeLa and HepG2 were plated at a density of $5 \times 10^{4}$ cells $/ \mathrm{mL}$, and then treated with varied concentration $(10,20,40,80,160 \mu \mathrm{M})$ of the compounds. The culture medium was removed from the plates after 48 and $72 \mathrm{~h}$ of culture, and each well was washed once
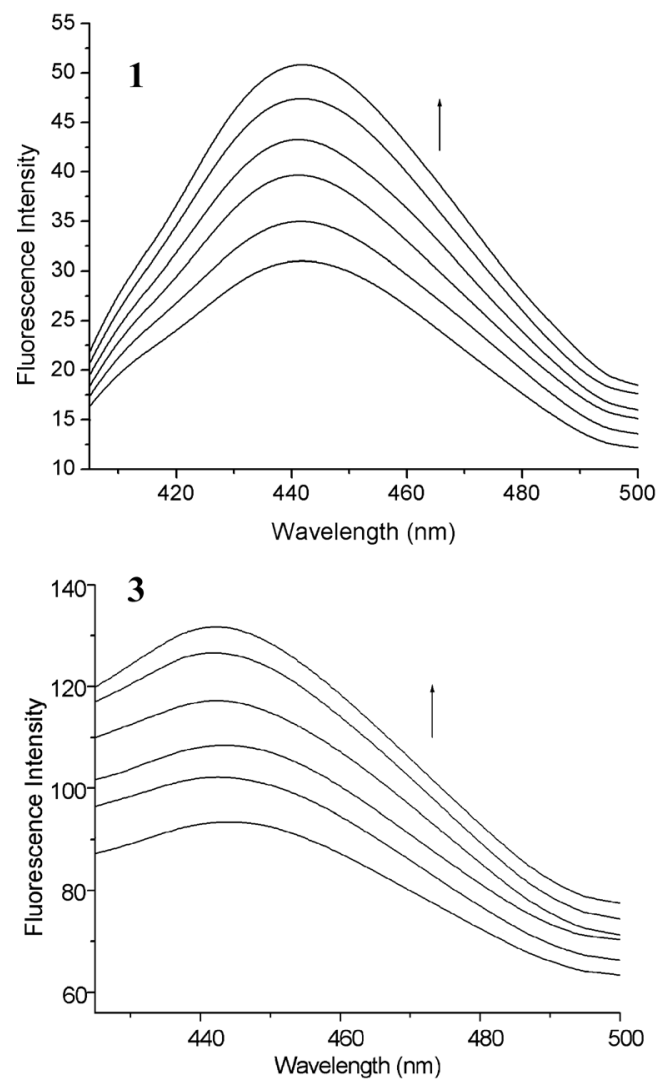

with $200 \mu \mathrm{L}$ phosphate-buffered saline (PBS, $\mathrm{pH}=7.2$ ). To each well, $100 \mu \mathrm{L}$ of buffer containing $0.1 \mathrm{M}$ sodium acetate $(\mathrm{pH}=5.0), 0.1 \%$ Triton $\mathrm{X}-100$ and $5 \mathrm{~mm} p$-NPP was added. The reaction was stopped with the addition of $10 \mu \mathrm{L}$ of $1 \mathrm{M}$ $\mathrm{NaOH}$, and color development was assayed at $405 \mathrm{~nm}$ using a microplate reader $\left(\right.$ Victor $^{3}$ 1420-050). The nonenzymatic hydrolysis of the $p$-NPP substrate was determined for each assay by including wells that did not contain cells as blank wells. Cell survival was expressed as an absorbance $(A)$ percentage defined by $\left(A_{\text {drug-blank }} / A_{\text {control-blank }} \times 100\right)$.

\section{Results and Discussion}

Absorption Spectra Electronic absorption spectroscopy is universally employed to examine the binding mode of DNA with small molecules. The absorption spectra of 1-4 in the absence and presence of ct DNA are given in Fig. 2. It can be seen that the absorption bands of 1-4 showed hypochromisms as well as slight red shift upon increasing DNA concentration. These phenomena indicated that the xanthones probably interact with ct DNA by intercalation mode, involving strong $\pi$-stacking interactions between xanthone rings of the compounds and DNA base pairs. ${ }^{22)}$

In order to study the binding ability of the compounds with DNA quantitatively, the binding constant $K_{\mathrm{b}}$ was determined

Table 1. The $K_{\mathrm{b}}$ of Xanthone Derivatives

\begin{tabular}{ccccc}
\hline \hline & $\mathbf{1}$ & $\mathbf{2}$ & $\mathbf{3}$ & $\mathbf{4}$ \\
\hline$K_{\mathrm{b}} \times 10^{4} \mathrm{M}^{-1}$ & 2.3 & 1.6 & 4.0 & 3.2 \\
\hline
\end{tabular}
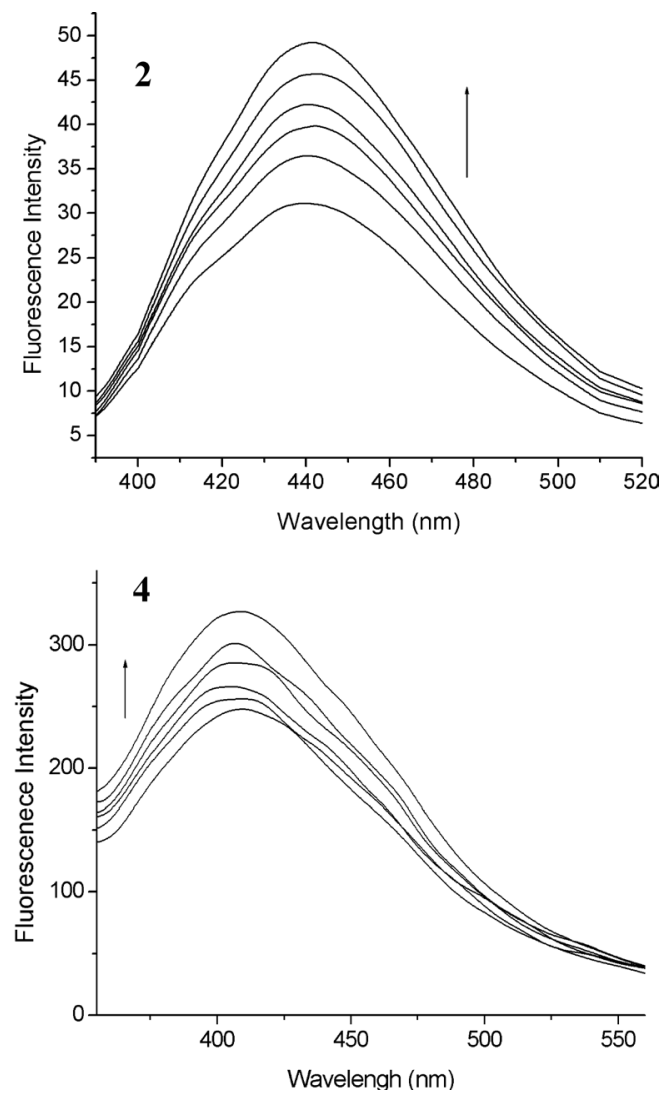

Fig. 3. Fluorescence Emission Spectra of Xanthones in the Presence of Increasing Amounts of ct DNA

$\lambda_{\mathrm{ex}}=312 \mathrm{~nm}, \lambda_{\mathrm{em}}=415-450 \mathrm{~nm} . C_{1-4}=10 \mu \mathrm{M}, C_{\mathrm{DNA}}=0,5,10,15,20,25 \mu \mathrm{M}$. 
by the Eq. $1,{ }^{23)}$

$$
[\mathrm{DNA}] /\left(\varepsilon_{\mathrm{a}}-\varepsilon_{\mathrm{f}}\right)=[\mathrm{DNA}] /\left(\varepsilon_{\mathrm{b}}-\varepsilon_{\mathrm{f}}\right)+1 / K_{\mathrm{b}}\left(\varepsilon_{\mathrm{b}}-\varepsilon_{\mathrm{f}}\right)
$$

where [DNA] is the concentration of DNA in base pairs, $\varepsilon_{\mathrm{a}}$, $\varepsilon_{\mathrm{f}}$, and $\varepsilon_{\mathrm{b}}$ are the apparent extinction coefficient correspond to $A_{\text {obsd }} /[M]$, the extinction coefficient for the free compound and the extinction coefficient for the compound in the fully bound form, respectively. In the plots of [DNA] $/\left(\varepsilon_{\mathrm{a}}-\varepsilon_{\mathrm{f}}\right)$ versus [DNA], $K_{\mathrm{b}}$ is given by the ratio of slope to the intercept (Fig. 2, inset). The binding constants $K_{\mathrm{b}}$ for $\mathbf{1} \mathbf{- 4}$ are summarized in Table 1 . So the order of the binding affinity is $\mathbf{2}<\mathbf{1}<\mathbf{4}<\mathbf{3}$ by comparing the binding constant values.

Fluorescence Spectra The binding mode of DNA with the isoeuxanthone derivatives was also investigated using fluorescence spectroscopy. In Tris- $\mathrm{HCl}$ buffer, the xanthones had fluorescence around $415-440 \mathrm{~nm}$ when excited at $312 \mathrm{~nm}$. If DNA solution is added to the xanthone solution, enhanced fluorescence is observed when excited under the given conditions. Fixed amounts $(10 \mu \mathrm{M})$ of the compounds were titrated with increasing amounts of ct DNA. Emission spectra for 1-4 are shown in Fig. 3. Enhanced fluorescence intensity was obtained with increasing DNA concentration indicating a deep intercalation of the xanthones with DNA. The results are in agreement with other intercalators, ${ }^{24)}$ suggesting efficient protection of the compounds from water by the hydrophobic environment inside the DNA helix. This will restrict the mobility of the compounds at the binding sites and decrease their vibrational modes of relaxation.
DNA-EB Displacements By measuring the ability of a compound to affect the EB fluorescence intensity in the DNAEB adduct, the binding mode and affinity of the compound for DNA can be determined. If a compound can replace EB from DNA-EB, the fluorescence of the solution will decrease due to the fact that free EB molecules are readily to be quenched by the surrounding water molecules. ${ }^{25)}$ Figure 4 showed the emission spectra of DNA-EB system upon the increasing amounts of xanthone derivatives. The emission intensity of DNA-EB system at $587 \mathrm{~nm}$ decreased as the concentration of xanthones increased and an isosbestic point appears around $525-540 \mathrm{~nm}$ for the alkoxy substituted xanthones. This indicated that xanthone derivatives could displace EB from the DNA-EB system and induce the translocation of EB from a hydrophobic environment to an aqueous environment. ${ }^{26)}$ Such a characteristic change is often observed in intercalative DNA interactions. ${ }^{27)}$

Interaction mode of compound binding to DNA can be determined according to the classical Stern-Volmer Eq. $2^{28)}$ :

$$
F_{0} / F=1+K_{\mathrm{q}}[Q]
$$

Where $F_{0}$ and $F$ represent the emission intensity in the absence and presence of quencher, respectively, $K_{\mathrm{q}}$ is a linear Stern-Volmer quenching constant and $[Q]$ is the quencher concentration. The quenching plots illustrated that the quenching of EB bound to DNA by the compounds is in good agreement with the linear Stern-Volmer equation (Fig. 4, inset). In the plots of $F_{0} / F$ versus $[Q], K_{\mathrm{q}}$ is given by the ratio of the
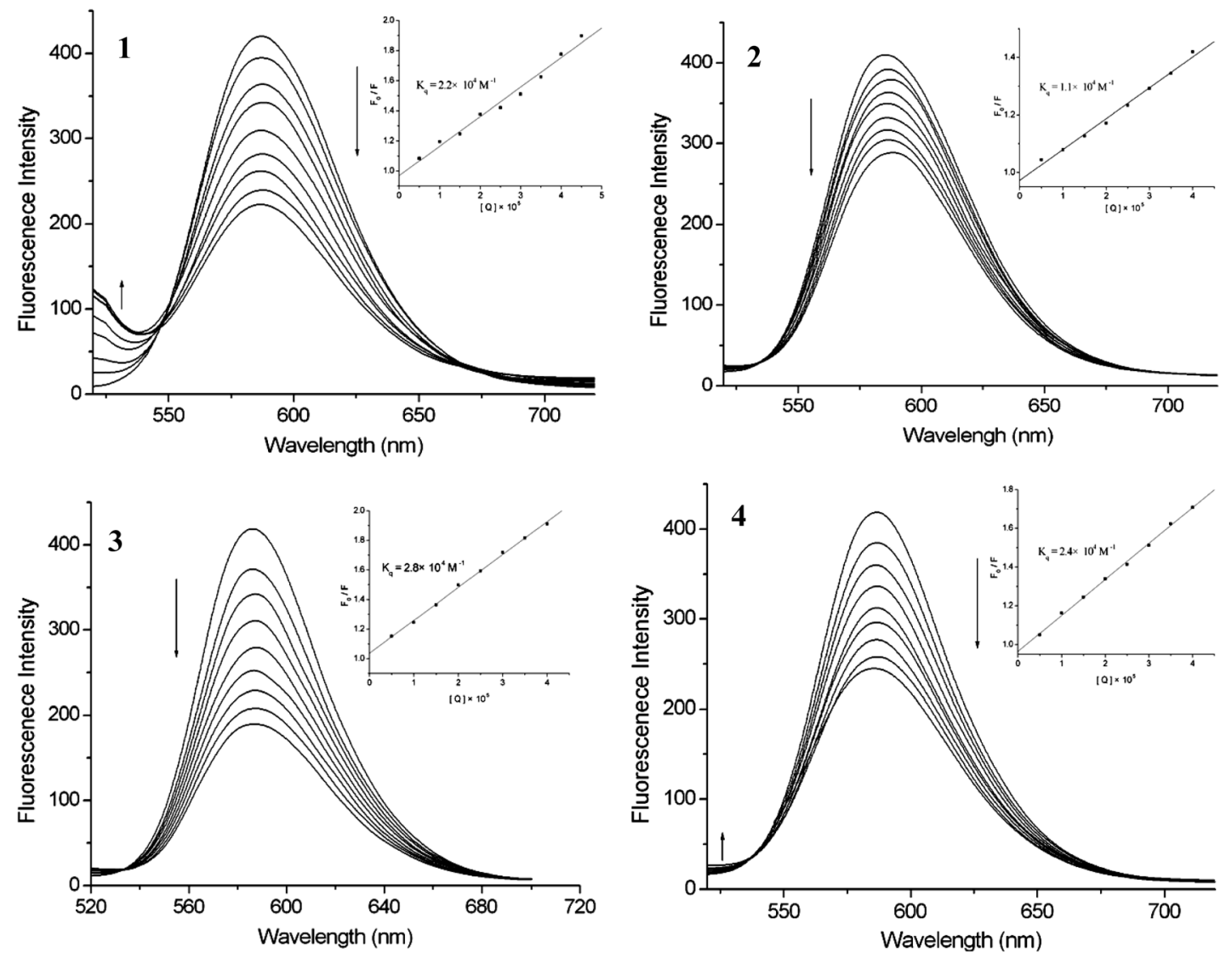

Fig. 4. Fluorescence Emission Spectra of DNA-EB in the Presence of 0, 5, 10, 15, 20, 25, 30, 35, $40 \mu \mathrm{M}$ of Xanthone Derivatives 1-4 $\lambda_{\mathrm{ex}}=500 \mathrm{~nm}, \lambda_{\mathrm{em}}=520-700 \mathrm{~nm}$. [EB] $=3 \mu \mathrm{M},[\mathrm{DNA}]=30 \mu \mathrm{M}$. The inset is Stern-Volmer quenching plots of the fluorescence titration. 
Table 2. The $K_{\mathrm{q}}$ and $\mathrm{IC}_{50}$ Values of Xanthone Derivatives $\mathbf{1}-\mathbf{4}$ in EB Displacement Experiments ${ }^{a)}$

\begin{tabular}{lllll}
\hline \hline & $\mathbf{1}$ & $\mathbf{2}$ & $\mathbf{3}$ & $\mathbf{4}$ \\
\hline$K_{\mathrm{q}} \times 10^{4}$ & 2.2 & 1.1 & 2.8 & 2.4 \\
$\mathrm{IC}_{50} \times 10^{-4}(\mathrm{M})$ & 0.45 & 0.91 & 0.36 & 0.42 \\
\hline
\end{tabular}

a) $\mathrm{IC}_{50}$ represents the concentration of quencher that is required for $50 \%$ quenching.

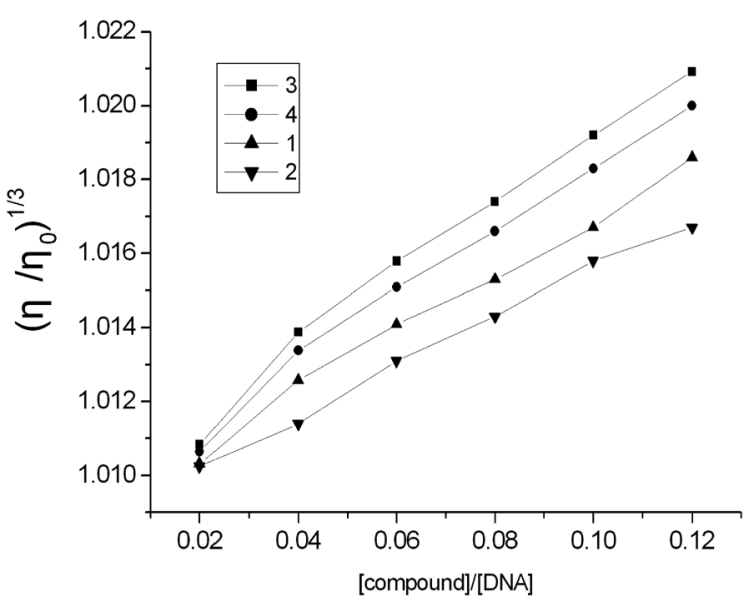

Fig. 5. Effect of Increasing Amounts of 1-4 on the Relative Viscosity of ct DNA at $25^{\circ} \mathrm{C}$

$[$ DNA $]=50 \mu \mathrm{M}$, [compound $]=1,2,3,4,5,6 \mu \mathrm{M}$.

slope to the intercept. The $K_{\mathrm{q}}$ and $\mathrm{IC}_{50}$ values for the xanthones are summarized in Table 2 , so the order of the binding affinity were $\mathbf{2}<\mathbf{1}<\mathbf{4}<\mathbf{3}$ by comparing quenching constant values. Moreover, as these changes indicate only one quenching process, it may be concluded that the compounds bind to DNA solely by intercalation mode. The results are in consistent with the binding constants determined by electronic absorption spectroscopy.

Viscosity Measurements Optical photophysical probes generally provide necessary, but not sufficient clues to support binding mode. Hydrodynamic measurements that are sensitive to length change (i.e., viscosity and sedimentation) are regarded as the least ambiguous and the most critical tests of binding in solution in the absence of crystallographic structural data. A classical intercalation model results in lengthening the DNA helix as base pairs are separated to accommodate the binding small molecules, leading to an increase of DNA viscosity. In contrast, a partial and non-classical intercalation of small molecules could bend or kink the DNA helix, reduce its effective length and, concomitantly, its viscosity. ${ }^{29,30)}$

To confirm the above inferences, viscosity measurements were carried out and the results were presented as $\left(\eta / \eta_{0}\right)^{1 / 3}$ versus binding ratio, where $\eta$ was the viscosity of DNA in the presence of xanthone derivatives, and $\eta_{0}$ was the viscosity of DNA alone. Viscosity values were calculated from the observed flow time $(t)$ of DNA-containing solution corrected from the flow time of butter alone $\left(t_{0}\right), \eta=t-t_{0}{ }^{20,21)}$ The effects of the compounds on the viscosity of DNA at $25.0^{\circ} \mathrm{C}$ are shown in Fig. 5. It could be observed that the viscosity of the DNA increased steadily with increasing amounts of 1-4. Such behavior is in accordance with other intercalators, which increases the relative specific viscosity for the lengthening of the DNA double helix resulting from intercalation. As (a)

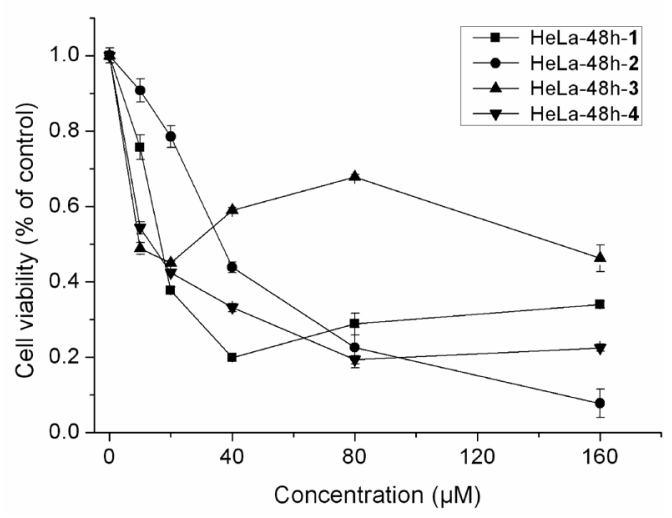

(b)

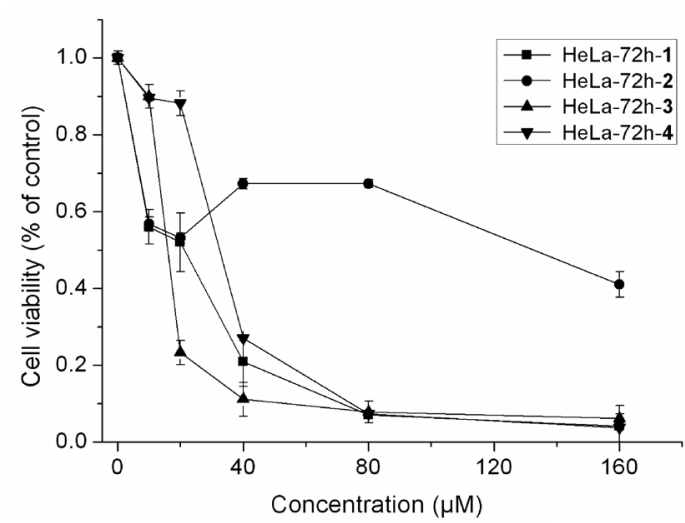

(c)

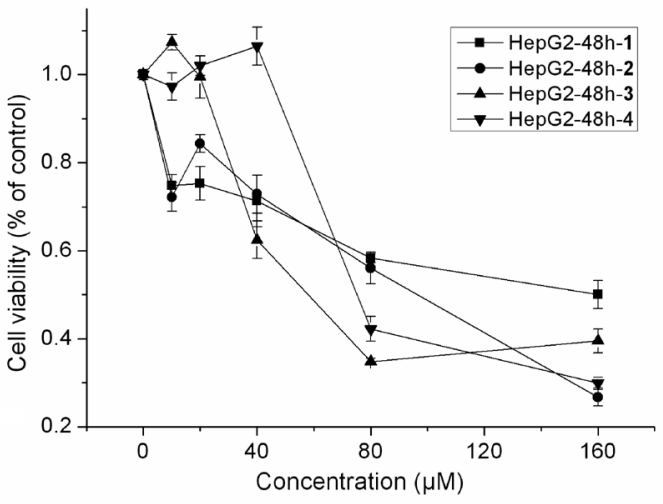

(d)

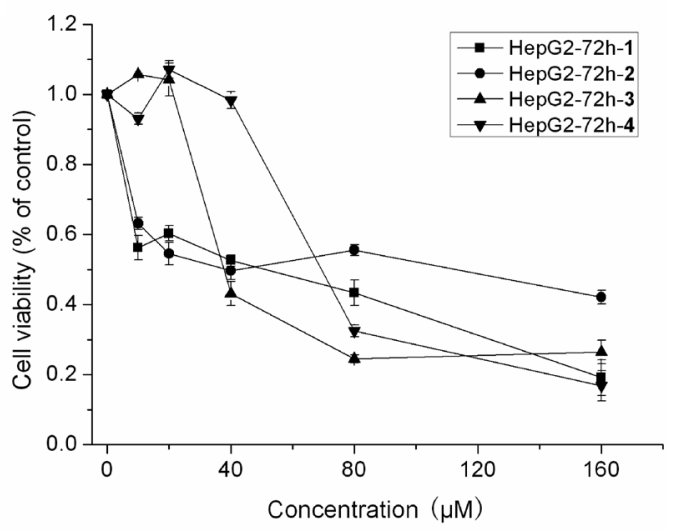

Fig. 6. Effects of 1-4 on Viability of HeLa (a) (b) and HepG2 (c) (d) Cells

Cells were treated with various concentrations of 1-4 for indicated duration. Each data point represents the arithmetic mean \pm S.D. of three independent experiments. 
Table 3. Antiproliferative Effects $\left(\mathrm{IC}_{50}\right)$ of $\mathbf{1 - 4}$ on $\mathrm{HeLa}$ Cells and HepG2 Cells

\begin{tabular}{ccccc}
\hline \hline \multirow{2}{*}{ Compounds } & \multicolumn{2}{c}{ HeLa cells $(\mu \mathrm{M})$} & \multicolumn{2}{c}{ HepG2 cells $(\mu \mathrm{M})$} \\
\cline { 2 - 5 } & $48 \mathrm{~h}$ & $72 \mathrm{~h}$ & $48 \mathrm{~h}$ & $72 \mathrm{~h}$ \\
\hline $\mathbf{1}$ & 17 & 21.5 & 160 & 43 \\
$\mathbf{2}$ & 37 & $>160$ & 98 & 26 \\
$\mathbf{3}$ & 10 & 16 & 56 & 38 \\
$\mathbf{4}$ & 14 & 33 & 75 & 70 \\
\hline
\end{tabular}

shown in Fig. 5, the increased degree of viscosity, which may depend on the binding affinity to DNA, follows the order of $\mathbf{2}<\mathbf{1}<\mathbf{4}<\mathbf{3}$. These agree with the results of the competitive binding experiment. The results demonstrated that the xanthones could intercalate between adjacent DNA base pairs, causing an extension in the helix, and the binding affinity of 3 is higher than that of the other compounds. The results obtained from viscosity studies also validate those obtained from the spectroscopic studies. On the basis of all the spectroscopic studies together with the viscosity measurements, we draw the conclusion that the compounds $\mathbf{1}-\mathbf{4}$ could bind to ct DNA in intercalative mode.

Pharmacology The xanthone derivatives were evaluated for their cytotoxic activity in vitro against HeLa and HepG2. The cell lines were incubated for $48 \mathrm{~h}$ and $72 \mathrm{~h}$ with varying concentrations of the xanthones. The cell viability was determined by acid phosphatase assay. The assay is based on the hydrolysis of the $p$-nitrophenyl phosphate by intracellular acid phosphatases in viable cells to produce $p$-nitrophenol. For the cell lines examined, absorbance of $p$-nitrophenol at $405 \mathrm{~nm}$ is directly proportional to the cell number in the range of $10^{3}-10^{5}$ cells.

The cell viability were decreased in response to xanthone derivatives 1-4 in a dose-dependent manner as illustrated in Fig. 6. These compounds exhibited certain cytotoxic activity against the two human tumor cell lines. The results demonstrated that the two tumor cell lines were susceptible to the xanthones. It may because the compounds intercalate into the base group pairs of DNA, which induce damage to DNA in the cancer cells, inhibit the division of cancer cells and result in cell death. ${ }^{31)}$ Combining with the DNA-binding experiment, it's possible that the different substitute groups could influence the electron cloud density change of xanthone ring by different level. And the increased aromaticity and the concentrated negative charge centers would cause the molecular show a stronger polarity. The molecular polarity changes related to DNA binding affinity. The flexible chain with active group linked at rigid xanthone plane may enhance the DNA binding affinity and facilitate the DNA selective binding, ${ }^{32)}$ which implied that the various substituent flexible side chains in xanthone derivatives might contribute to the increase of their anticancer activity or to the decrease of their toxicity.

Comparing to the $\mathrm{IC}_{50}$ values of the xanthone derivatives 1-4 against various human cancer cells, the oxiranylmethoxy substituted xanthones have efficiently inhibited growth of the two cancer cells. The other group substituted xanthones have inhibited growth of different cancer cells (Table 3). This suggested that the cytotoxic activity of the same compound against one tumor cell line differ from another. It is likely that the exact action mechanisms of xanthones against tumor cell lines are different from each other because of the multiple structures and compositions in various tumor cell lines. The complicated mechanisms about the effect of the compounds on the tumor cells are currently under the way.

\section{Conclusion}

The interaction mode between DNA and a series different substituted xanthones have been investigated by spectrophotometric methods and viscosity measurements. The results suggested that the xanthones could intercalate into the base group pairs of DNA because of the good planarity of their aromatic ring. They all have strong binding affinity with DNA. Comparing the binding extents of them, it is concluded that the binding affinity of oxiranylmethoxy substituted isoeuxanthone is stronger than that of the other group substituted xanthones. The result of inhibitory effect in vitro is consistent with the result of DNA binding study. And each compound would show the cytotoxic activity varying according to the various tumor cells. We concluded that the xanthones intercalate between DNA base pairs and may cause DNA damage in cancer cells, thus inhibit the division of cancer cells. Information obtained from the present work provides evidence for the nature of the binding of the xanthones to DNA and is expected to offer further impetus for designing newer probes for DNA structure and novel therapeutic agents that are directed at DNA.

Acknowledgments We are grateful for the financial support of the National Natural Science Foundation of China (No. 21306124) and the National Science Foundation of Shanxi Province (No. 2012021008-4 and No. 2011011022-2).

\section{References}

1) Vieira L. M., Kijjoa A., Curr. Med. Chem., 12, 2413-2446 (2005).

2) Azevedo C. M. G., Afonso C. M. M., Pinto M. M. M., Curr. Org. Chem., 16, 2818-2867 (2012).

3) Jung H. A., Su B. N., Keller W. J., Mehta R. G., Kinghorn A. D., J. Agric. Food Chem., 54, 2077-2082 (2006).

4) Lee B. W., Lee J. H., Lee S. T., Lee H. S., Lee W. S., Jeong T. S., Park K. H., Bioorg. Med. Chem. Lett., 15, 5548-5552 (2005).

5) Ignatushchenko M. V., Winter R. W., Bachinger H. P., Hinrichs D. J., Riscoe M. K., FEBS Lett., 409, 67-73 (1997).

6) Lin C. N., Chung M. I., Liou S. J., Lee T. H., Wang J. P., J. Pharm. Pharmacol., 48, 532-538 (1996).

7) Pedro M., Cerqueira F., Sousa M. E., Nascimento M. S., Pinto M., Bioorg. Med. Chem., 10, 3725-3730 (2002).

8) Valenti P., Bisi A., Rampa A., Belluti F., Gobbi S., Zampiron A., Carrara M., Bioorg. Med. Chem., 8, 239-246 (2000).

9) Yoshimi N., Matsunaga K., Katayama M., Yamada Y., Kuno T., Qiao Z., Hara A., Yamahara J., Mori H., Cancer Lett., 163, 163-170 (2001).

10) Saraiva L., Fresco P., Pinto E., Sousa E., Pinto M., Goncalves J., Bioorg. Med. Chem., 10, 3219-3227 (2002).

11) Woo S., Kang D. H., Nam J. M., Lee C. S., Ha E. M., Lee E. S., Kwon Y., Na Y., Eur. J. Med. Chem., 45, 4221-4228 (2010).

12) Pace T. C., Monahan S. L., MacRae A. I., Kaila M., Bohne C., Photochem. Photobiol., 82, 78-87 (2006).

13) Shen R., Wang P., Tang N., J. Fluoresc., 20, 1287-1297 (2010).

14) Wang H. F., Shen R., Tang N., Eur. J. Med. Chem., 44, 4509-4515 (2009).

15) Wang H., Wei L., Yan H., Gao X., Xu B., Tang N., Chem. Pharm. Bull., 61, 599-603 (2013).

16) Liu Y., Zou L., Ma L., Chen W. H., Wang B., Xu Z. L., Bioorg. Med. Chem., 14, 5683-5690 (2006). 
17) Wang T.-C., Zhao Y.-L., Liou S.-S., Helv. Chim. Acta, 85, 13821389 (2002).

18) Carter M. T., Rodriguez M., Bard A. J., J. Am. Chem. Soc., 111, 8901-8911 (1989).

19) Kumar C. V., Asuncion E. H., J. Am. Chem. Soc., 115, 8547-8553 (1993).

20) Eriksson M., Leijon M., Hiort C., Nordén B., Gräslund A., Biochemistry, 33, 5031-5040 (1994).

21) Xiong Y., He X.-F., Zou X.-H., Wu J.-Z., Chen X.-M., Ji L.-N., Li R.-H., Zhou J.-Y., Yu K.-B., J. Chem. Soc., Dalton Trans., 1999, 19-24 (1999).

22) Kelly J. M., Murphy M. J., McConnell D. J., OhUigin C., Nucleic Acids Res., 13, 167-184 (1985).

23) Tabassum S., Khan R. A., Arjmand F., Sen S., Kayal J., Juvekar A. S., Zingde S. M., J. Organomet. Chem., 696, 1600-1608 (2011).
24) Satyanarayana S., Dabrowiak J. C., Chaires J. B., Biochemistry, 31, 9319-9324 (1992)

25) Lippard S. J., Acc. Chem. Res., 11, 211-217 (1978).

26) Zeng Y. B., Yang N., Liu W. S., Tang N., J. Inorg. Biochem., 97, 258-264 (2003)

27) Kumar C. V., Barton J. K., Turro N. J., J. Am. Chem. Soc., 107, 5518-5523 (1985).

28) Eftink M. R., Ghiron C. A., Anal. Biochem., 114, 199-227 (1981).

29) Zou X.-H., Ye B.-H., Li H., Liu J.-G., Xiong Y., Ji L.-N., J. Chem. Soc., Dalton Trans., 1423-1428 (1999).

30) Sigman D. S., Mazumder A., Perrin D. M., Chem. Rev., 93, 2295 2316 (1993).

31) Zuber G., Quada J. C., Hecht S. M., J. Am. Chem. Soc., 120, $9368-$ 9369 (1998)

32) Shen R., Wang P., Tang N., J. Fluoresc., 20, 1287-1297 (2010). 